\title{
Az öncélú hatékonyság kultusza
}

\author{
DARUKA ISTVÁN ${ }^{1}$
}

\begin{abstract}
ABSZTRAKT
A jelen esszé körüljárja a technokapitalista nyugatias modernitás öncélú hatékonyságkultuszát, bemutatva annak profitvezérelt, kompulzív, teljesítménykényszeres trendjeit, amelyek természetszerüleg vezetnek mind az egyének, mind pedig a globalizált világtársadalom dehumanizációjához, dekontextualizációjához. Ezen esszé egyben egy felkiáltás is, az emberért, az emberségért, amelyet a jelen írás „impresszionista” stílusa és humanizált narratívája tesz talán még érzékletesebbé.
\end{abstract}

KULCSSZAVAK: öncélú hatékonyság, technokapitalizmus, hasított időpercepció, egzisztenciális szorongás, teljesítménykényszer, profithajsza, társadalmi bizonytalansági relációk

\section{ABSTRACT}

\section{The Cult of Reflexive Efficacy}

This essay elaborates on the reflexive efficacy cult of the technocapitalistic Western modernity, unequivocally demonstrating its profit-driven, compulsive trends which naturally lead to dehumanization and decontextualization both on the individual and societal levels. As such, the present work is also an exclamation for humans, for humanism, being further supported by its "impressionist" style and humanized narrative.

KEYWORDS: reflexive efficacy, technocapitalism, broken time perception, existential anxiety, compulsive producion, profit race, social uncertainty relations

Hatékonyságvezérelt mindennapjainkban effektív társadalmi döntési terünk talán nem is több már, mint egy szakadékba zuhanó autóban azt mérlegelni, hogy bekapcsoljuk-e a klímát, vagy sem: elolvassam-e ezt a Metszetek cikket, vagy sem? De vigyázzon, kedves Olvasó! Amennyiben az elolvasás mellett dönt, az megzavarhatja

${ }^{1}$ Tudományos főmunkatárs, Semmelweis Egyetem Általános Orvostudományi Kar, Biofizikai és Sugárbiológiai Intézet. 


\section{TEMATIKUS TANULMÁNYOK - Hozzászólás}

hatékonyságvezérelt gondolatait, sőt mi több, jelentős kieséseket okozhat kitüntetett profittermelő tevékenységében is!

Valóban. Teljesítmény- és időkényszeres világban élünk. Megy a hajsza, a könyörtelen profitvadászat. A csillogó, békés színfalak mögött egymást tapossák, ölik az emberek. Vagy pedig saját magukat nyomják el, teszik tönkre, hogy olajozottan működő, megbecsült, konform fogaskerekek lehessenek a nagy gépezetben. Teszik mindezt mosolyogva egy névlegesen jobb, békésebb, fenntarthatóbb világ létrehozása érdekében. Hogy le ne maradjanak, a hit, erkölcs, emberség ódivatú ballasztjait rég kidobták már, de erősen kopik, töredezik a polkorrekt zománc is. Sőt mi több, ott tartunk, hogy már-már bűnné, de legalábbis jelentős versenyhátránnyá válik a becsület, az őszinteség. Ha akadna még egyáltalán valaki, aki tudja, hogy mit is jelenthettek valójában ezek a mára kiüresedett humán-attribútumok.

Ahogyan erősödik a technokapitalista teljesítmény- és profitkényszer, úgy válnak egyre fontosabbá a rövidtávú előnyök („itt és most”) a potenciális hosszútávú hátrányokkal („,bizonytalan, távoli jövendő”) szemben. Ez az időskálák közötti egyre növekvő, sőt öngerjesztő feszültség egy perceptív szakadáshoz vezet, az időskálák közötti hasításhoz. Irreverzibilisen is megszűnik a nyugalom, a végtelenből véges lesz (Daruka 2013). Az ilyen értelemben vett hasított, szimmetriasértett nyugatias modernitásban természetszerűleg erősödik a sietség, a hajsza. S ahogyan duzzad a profitlavina, ennek saját, öngerjesztő erőtere elnyom, maga alá temet minden más (emberi, természeti stb.) szempontot, értéket. Ezáltal a társadalmi, mentális metrika egydimenzióssá redukálódik és bezáródik (Marcuse 1990). A GDP alapú technokapitalizmus dehumanizált, egydimenziós világa ez.

A tudomány a számalapú profitmaximalizációt leghatékonyabban kiszolgáló keretrendszer, s ezen minőségében mint a technokapitalizmus egyik hajtómotorjára is tekinthetünk. A technokapitalista világgazdasággal szoros csatolásban fejlődő tudomány manapság megkérdőjelezhetetlen, megkerülhetetlen fellegvárrá vált, sőt egyesek a tudomány önkényuralmáról [Feyerabend], mások viszont már a tudomány alkonyáról is értekeznek (Corredoira 2013).

A technokapitalista nyugatias modernitás időpercepcióját a végesség, a dekontextualizált hasítottság jellemzi, ellentétben a természeti népek folytonos, koherens „végtelen” időszemléletével (Fejős; Daruka 2013). A globalizált technokrata ember elszakadt a természettől, természetes belső ritmusától. Ennek hiányában viszont szüksége van egy külső, objektív, szinkronizált időre, amely segítségével még hatékonyabban dolgozhat (Fejős 2000).

A véges, hasított technokapitalista időszemlélet természetszerűleg felértékeli magát az objektív, szinkronizált időt: „az idő pénz”, mondják. S mivel véges, sietni kell, indul a hajsza, az öngerjesztő profithajsza. Az egydimenziós profitmaximalizáció természetszerűen elvezet a hatékonyság fokozásához, egyfajta öncélú hiperversenyhez (Edwards 2016). Sőt mi több, a hatékonyság fontossága már-már élet-halál 


\section{TEMATIKUS TANULMÁNYOK - Hozzászólás}

kérdéssé válik. Ily módon a nyugatias modernitás embere észrevétlenül csusszan bele a túlhajtott hatékonyság láthatatlan falú, időtlen börtönébe.

Természetesen régebbi korokban, ill. más kultúrákban is jelen volt/van a hatékonyság, ez egy adott szintig mindenképpen konstruktív entitásnak tekintendő és a hosszú távú fenntarthatósággal kapcsolatos evolúciós előnyt jelent egyben. A fentiek alapján megkülönböztethetjük tehát a konstruktív, humanizált hatékonyságot a túlhajtott, kényszeres, öncélú, destruktív hatékonyságtól.

A kvantummechanikából ismert, hogy bizonyos fizikai entitásokat egyidejúleg nem lehet tetszőleges pontossággal meghatározni, megmérni. A vonatkozó Heisenberg-féle határozatlansági relációk reciprocitási összefüggést teremtenek pl. az energia és az idő, ill. a sebesség és hely bizonytalanságai között. Úgy tűnik, hogy globalizált, erősen csatolt világtársadalmunkban is vannak olyan entitások, amelyek egyidejűleg nem növelhetők vagy csökkenthetők tetszőlegesen, mindinkább egymás rovására változnak, azaz egyfajta anti-korreláció mutatkozik közöttük. A Heisenberg-féle relációk mintájára, analóg módon, szemléltető jelleggel felírhatjuk a technokapitalizmusra vonatkozó két alapvető, kvalitatív határozatlansági relációt (az „energia $\rightarrow$ profit"; „idő $\rightarrow$ emberség”; „,hatékonyság $\rightarrow$ sebesség”; „hely $\rightarrow$ látókör” analóg megfeleltetésekkel):

\section{Profit $\times$ emberség $=$ konstans}

$$
\text { Hatékonyság } \times \text { látókör = konstans. }
$$

Az első reláció vélhetően magától értetődő. A másodikkal kapcsolatban megjegyezzük, hogy minél gyorsabban, „hatékonyabban” haladunk egy járművel, annál szúkebb lesz az a térrész, amelyre koncentrálunk a hatékonyabb haladás, a célzott „előrejutás” érdekében. Beszűkül az eseményhorizont, mondhatjuk. Einstein feltette a kérdést, hogy vajon mit lát a foton, a leggyorsabban száguldó részecske. Semmit. Vak. A végtelen hatékony száguldás időtlen vakságában szenved. Végül, a teljesítménykényszeres tudományos publikációdömping korszakában még egy harmadik intuitív relációt is felvázolhatunk a tudományos folyóiratok piedesztálra emelt impakt faktorára vonatkozóan:

\section{(Impakt faktor) $\times$ (gondolati szabadság) $=$ konstans. (3)}

Fontos megemlítenünk, hogy ezen társadalom-, illetve publikációdinamikai határozatlansági relációk (1-3) a benne foglalt entitások nem kvantifikálható mivolta miatt csupán kvalitatív, szemléltető jellegűek, viszont ennek ellenére is igen érzékletesek, inspirálóak maradnak, fontos társadalom- és kutatásdinamikai problémákra irányítva a figyelmet. 


\section{TEMATIKUS TANULMÁNYOK - Hozzászólás}

Az öncélú hatékonyság a gyorsaság, a direkt produktumú teljesítmény analógiájává válik. Előtérbe kerülnek a gyorsabb, keményebb módusok, s háttérbe szorulnak a lassabb, gyöngédebb módusok. Bekeményít, dogmatikusan megmerevedik a technokapitalista világ, s ebben a fejvesztett hajszában a dehumanizált, humán-hasított „hard science” természetszerűleg „diadalmaskodik”, egyeduralkodóvá válik a humaniórák felett. Az eszeveszett rohanásban a legtöbben már nem is látják, nem is érzékelik talán, hogy mi minden értékes, emberi vész el. Nincs már szükség gondolati, szellemi mélységre, belső integritásra, ezek mielőbb eldobandó ballasztként jelentkeznek a hatékonyságvezérelt profithajszában. Mélységvesztésben vagyunk (Bánfalvi 2006).

Természetesen ezen gyökeres időpercepciós átalakulások, hatékonyság indukált teljesítménykényszer erősen befolyásolják magának az egyéni, illetve társadalmi sikernek, sikerességnek a fogalmát és koncepcióját is. A profitvezérelt materiális egydimenzionalitás természetszerűleg szelektálja, s részesít előnyben bizonyos személyiségtípusokat, erős személyiségszelekciós nyomást indukálva. A nagy stressztűrő képesség, funkcionális egyszerüség, rendszerkonformitás, gyors adaptivitás, felfokozott mobilitás, anyagias, profitcentrált szemléletmód attribútumai rendszerszintű személyiségszelekciós előnyöket jelentenek. Ezen szelekciós folyamat természetéből fakadóan magában hordoz burkolt diszkriminációs trendeket is a hatékony profittermelés által nem preferált személyiségtípusokat illetően. A személyiségszelekción túlmenően, az egydimenziós profithajsza elvezet egy markáns betegség/ tünetszelekciós folyamathoz is, amint azt majd a depresszió-munkamánia taglalásánál látni fogjuk.

A túlhajtott, öngerjesztő hatékonyság szervesen átszövi mindennapjainkat, jelen van munkánkban, döntéseinkben, kapcsolatainkban, szemléletmódunkban, s erősen kihat kísérő lelki jelenségeinkre, belső, mentális dinamikánkra is. Joggal érezhetjük, hogy nem a hatékonyság van értünk, hanem már-már mi vagyunk a profittermelő hatékonyságért. Globalizált világunkban nagyszámú ember (s sajnos egyre többen) a túlhajtott hatékonyság, a teljesítménykényszeres stressz, illetve egzisztenciális szorongások áldozatának/betegének tekinthető (Kopp 2004). Sokan terápiára is szorulnak stresszindukált állapotuk, pszichoszomatikus betegségeik miatt. S hogy mások kihasználásából, betegségéből egyesek busás anyagi hasznot húznak - természetesen a hatékonyság nevében - kit is érdekel már.

A túlhajtott hatékonyság összezsugorítja az időt, s szorongást kelt. Mindent most, az adott pillanatban szeretnének elérni, megvalósítani az emberek. Azonnal és költséghatékonyan, időhatékonyan. Az orvoslásban is megjelenik a túlhajtott hatékonyság, a csúcsra járatott technomedicina éllovasa ezen trendeknek. Hiszen akár több év szorongásaiból, belső konfliktusaiból kifejlődött testi tünetet egy pillanat alatt kivág a lézerszike, vagy akár egy csúcstechnológiás műtőrobot. Hasítás ez, a szó szo- 


\section{TEMATIKUS TANULMÁNYOK - Hozzászólás}

ros értelmében vett hasítás. A lelki, mentális hasítás testbe türemkedett szomatikus tüneteit teljes mértékben dekontextualizáltan, anyagi értelemben, materiálisan hasítják ki. Mindezt egy pillanat alatt. Természetesen vannak esetek, amikor más megoldás már nem is jöhet szóba, s ilyen értelemben a technomedicina hasznosnak, sőt akár életmentőnek is tekinthető. De a legfontosabb kérdés talán az, hogyan alakulhatott ki az az abszurd, katasztrofális egészségügyi helyzet, hogy világszerte embertömegek szoruljanak a dehumanizált technomedicina hatékony segítségére.

A humanizált terápiára persze nincs idő, rohanni kell. Költséghatékonyan, öncélúan, dehumanizáltan. Rohanni és kész. A csúcstechnológiás technomedicina hatékony, fájdalommentes kognitív, illetve biomedikális tünetkasztrálást ajánl fel és valósít meg. Ráadásul rengeteg profitot termel. Vajon lehet versenyezni mindezzel? Ki akarja ma már megérteni, megélni fájdalmát, szenvedését, együtt lenni velük, mint inkább minél gyorsabban megszabadulni tőlük, idegen ellenségként tekinteni rájuk, háborúzni velük. Régebbi korokban, amikor az idő még nem raboskodott a profittermelő hatékonyság szűkmarkú börtönében, talán több idő jutott a betegségek kihordására, sőt mi több, tiszteletben tartására. Több, mint 400 évvel ezelőtt, azaz a felvilágosodást, tudományos forradalmat megelőzően Michel de Montaigne az alábbiakat írta a betegségekről, illetve betegségekhez való viszonyáról. Figyeljük meg, hogy milyen természetességgel, illetve tisztelettel közelít a betegségekhez (Montaigne 1992 o. n.):

„Én is úgy gondolom, mint Crantor, hogy nem szabad se makacsul, se hebehurgyán szembeszállni a nyavalyákkal, sem pedig gyengén meghajolni alattuk, de engedni kell nekik természet szerint, az ó állapotukhoz és a miénkhez képest. Hagyjuk a betegségeket szabadjára; mert úgy látom, kevesebbet idöznek nálam, aki nem állja útjukat; és el is múltak tőlem némelyek, habár a legmakacsabbak és legszívósabbak közé sorolják óket, pusztán a maguk hanyatlásából, segítség és orvoslás nélkül, sőt az orvosi szabályok ellenében. Hagyjuk egy kicsit szabadjára a természetet, jobban érti a dolgát, mint mi. ... Már többször hagytam megöregedni és természetes halállal elhalni magamban mindenféle náthát, köszvényt, hasmenést, szívdobogást, fejfájást, és más nyavalyákat, amelyek olyankor búcsúztak el tőlem, amikor félig már beleszoktam a vendégelésükbe. Udvariassággal könnyebb kiüzni őket, mint ellenkezéssel. Szelíden türnünk kell állapotunk törvényeit. Arra születtünk, hogy megöregedjünk, elgyöngüljünk, betegek legyünk, minden orvostudomány ellenére."

Amilyen ütemben növekszik a dehumanizált szorongás, olyan mértékben nő a ragaszkodás, az igény az objektivitásra, a konkrét, kézzel fogható tudományosságra, a számszerűsítésre, a mindenható mérésekre. Könnyen félre lehet persze siklani, lehet tévedni a szubjektív, humanizált megközelítések végtelen, képlékeny, állandóan 


\section{TEMATIKUS TANULMÁNYOK - Hozzászólás}

változó, egyszeri és megismételhetetlen labirintusában, az áltudományok szküllái és az ezotéria karübdiszei között. Természetesen a kemény tudományoknak is van létjogosultsága, konstruktív szerepe. Viszont a hasított, numerizált egyoldalúság, a dekontextualizált egyeduralkodás végett ezek hosszú távon destruktívvá válhatnak.

Egy tanulmány szerint, mivel a patogén társadalmi viszonyokat megváltoztatni nem lehet, inkább az egyént kezelik, azaz a társadalmi szintű problémákat áthelyezik az egyénre (Kovács 2004). A rövidtávon sikeres individualizált terápiák türőképesebb egyéneket állítanak elő, kontraindikatíve hosszabb távon tovább növelve viszont a rendszerszintű dehumanizációt, az általános elidegenedést, közönyt. Tovább fokozva természetesen az öngerjesztő profithajszát.

Felmerül továbbá a kérdés, hogy ebben a hatékony profithajszában, a technokapitalista modernitás futurisztikus fellegvárában mi szükség lehet még egyáltalán humanizált gyógykezelésre? Kinek az érdekeit szolgálhatja ez? Ugye a kellemetlen tüneteket senki sem kedveli, a rohanás, a hajsza kedvéért ellenségképp tekint rájuk, amitől minél hamarabb meg kell szabadulni, eliminálni kell őket. Minél gyorsabban, hatékonyabban. A pszichoszomatikus tünetek többsége viszont vélhetően éppen a kizsákmányolás, illetve az ezzel összefüggő hajszolt életmód által létrehozott frusztrációkból, feszültségekből, egzisztenciális szorongásokból táplálkozik. Ezek egyfajta védekező reakciónak tekintendők a dehumanizált, kollektivizált kizsákmányolás ellen. A költséghatékony terápia igen gyorsan, lendületesen kapcsolja ki ezen pszichoszomatikus vészjelzéseket, hogy baj van. Így minden mehet ugyanúgy tovább, mintha nem lenne semmi probléma sem (Daruka 2013).

Ily módon a tünetkasztráló gyógymódok, a költség- és időhatékony terápiák, azaz a szuppresszív medicina elősegítik a további dehumanizációt, tovább erősítve a globális tőkekoncentrációt, egy destruktív önerősítő ciklusba szerveződve. Mondhatnók a rendszerkonform költséghatékony terápiák manipulálják, szinkronizálják a dehumanizált tömegeket, pszeudo-koherens, racionalizált-szupportív érvrendszerek segítségével (Daruka 2014). Ezen költséghatékony megközelítések elsősorban tehát rövidtávú tüneti cementáló kezeléseknek tekinthetők, hosszútávon viszont kontraindikatívak lehetnek mind individuális, mind pedig társadalmi szinten is.

A tömegessé, már-már népbetegséggé váló depresszió kapcsán vezető közgazdászok arról vitatkoznak, hogy a depresszió mekkora károkat okoz a világgazdaságnak. Arra viszont egyáltalán nem térnek ki, hogy a világgazdaság vajon mekkora károkat okoz magának az emberiségnek. Míg a depresszió ellen világméretekben küzdenek, eliminálandó tünetként, betegségként tekintenek rá, addig a munkamánia jelenségéről nem igazán beszélnek. Noha a munkamánia is egy nagyon súlyos tünet/betegség lehet, akár bele is lehet halni. Japánban pl. külön szó jellemzi ezt a jelenséget: „,karoshi”-nak nevezik azt, ha valaki szó szerint halálra dolgozza magát. 


\section{TEMATIKUS TANULMÁNYOK - Hozzászólás}

Míg a depresszió csökkenti a profittermelést, addig a munkamánia növeli azt. Ezáltal a depresszióról és munkamániáról mint profitelvonó és profittermelő betegségekről is beszélhetünk. S ez a különbség egy diszkriminatív szimmetriasértéshez is vezet egyben: a depresszió ellen széleskörűen küzdenek, míg a munkamánia egy társadalmilag elfogadott, hallgatólagosan támogatott szalonbetegséggé válik.

A profitkényszer, profithajsza hatalmas nyomással nehezedik a munkavállalókra. A teendők, elvégzendő feladatok száma, mennyisége jóval túlmutat az emberek többségének munkakapacitásán, így időzavar, sőt krónikus időzavar alakul ki sokaknál. Paradox módon a hatékonyság túlzott hajszolása hosszabb távon magának a hatékonyságnak az effektív csökkenéséhez is vezethet. Ráadásul a sokrétű szabályozás, túlszabályozottság, bürokratizmus, igencsak beszúkíti az egyének cselekvési terét, egyfajta kommunikációs impotenciát eredményezve, amely szükségszerűen elvezet a gondolatilag kasztrált, politikailag korrekt elbeszélésmód tömeges elterjedéséhez. Ezek alapján úgy tűnik, hogy a szólásszabadság pontosan akkor válik elfogadottá rendszerszinten, amikor a szavak, írások effektíve impotenssé válnak, elveszítve egyéni és társadalmi funkciójukat is: csupán üresen csillogó szózománccá fonnyadnak, ráégnek a mindenható profitgépezet sérthetetlen pénzvázára.

\section{Összegzés}

A profitvezérelt technokapitalizmus természetszerúleg vezet a hatékonyság öngerjesztő fokozódásához, annak öncélúvá válásához, a vonatkozó mentális metrika egydimenzióssá redukálódásához, illetve tömeges elidegenedéshez (Fromm 2002, Turkle 2012). Mindezen folyamatok nyomában a békés, csillogó színfalak mögött kollektivizált feszültségek, egzisztenciális szorongások pszichoszomatikája húzódik meg, amelyekre a csúcstechnológiás technomedicina igen hatékony, sokrétủ és teljesen dehumanizált tünetkasztrációs megoldásokat kínál. Zárul a kör, összhangba kerül hát minden, hasít a hatékonyság. Csupán egy idejemúlt marginalizált entitás, az egyedi, esendő ember marad ki ebből a páratlan sikertörténetből, botladozó cammogása lassítaná ugyanis a profittermelő „haladást”.

Vélhetően néhányan elolvassák majd ezt a cikket, bólintanak egyet, fintorognak, vagy esetleg felháborodnak az olvasás miatt kiesett profittermés miatt. Így vagy úgy, aztán minden megy tovább, ahogyan eddig is, fokozódik a nemzetközi profithajsza, tovább dagad az öngerjesztő hatékonyságdogma, s felragyog a hatékony élettelenség csalfán csillogó tudományos diadala. 
www. metszetek.unideb.hu

\section{TEMATIKUS TANULMÁNYOK - Hozzászólás}

\section{Irodalom}

Bánfalvi A. (2006): Mélységvesztésben. Új Mandátum Könyvkiadó, Budapest.

Corredoira, M. L. (2013): The Twilight of the Scientific Age. Brown Walker Press.

Daruka I. (2013): Egészség vagy tünettelenség? Avagy a dekontextualizált medicina arcai. Lege Artis Medicinae 23 (5-6), 296-299.

Daruka I. (2014): Kiszámítható-e az emberi viselkedés? Lege Artis Medicinae 24 (10-11), 486-489.

Edwards, M. A. - Roy S. (2016): Academic Research in the 21st Century: Maintaining Scientific Integrity in a Climate of Perverse Incentives and Hypercompetition, Environmental Engineering Science - Special Issue: EES in the 21st century 00: 1-11.

Fejős Z. (2000) (szerk.): Idő és antropológia. Osiris Könyvkiadó, Budapest.

Feyerabend, P. (2011): The Tyranny of Science. Polity Press.

Fromm, E. (2002): Menekülés a szabadság elől. Napvilág Kiadó, Budapest.

Kopp M. S. - Réthelyi J. (2004): Where psychology meets physiology: chronic stress and premature mortality - the Central-Eastern European health paradox, Brain Research Bulletin 62, 351-367.

Kovács J. (2004): Pszichiátria és medikalizáció. A pszichiatrizálás okai. Lege Artis Medicinae 14 (7), 520-524.

Marcuse, H. (1990): Az egydimenziós ember. Kossuth Kiadó, Budapest.

Montaigne, de M. (1992): A tapasztalásról. Európa Könyvkiadó, Budapest.

Turkle, S. (2012): Alone Together: Why We Expect More from Technology and Less from Each Other, Basic Books. 